\title{
Benchmarking Study on the Level of Food Security of Southern Russia Regions on the Basis of Innovative Approaches
}

\author{
Galina Vladimirovna Timofeeva \\ Russian Presidential Academy of National Economy and \\ Public Administration \\ Faculty of Public Administration Economics \\ Moscow, Russia \\ gv.timofeeva@migsu.ranepa.ru
}

\author{
Raisa Isaevna Akmaeva \\ Astrakhan State University \\ Faculty of Business and Economics \\ Astrakhan, Russia \\ akmaevari@yandex.ru
}

\author{
Aigul Aldungarovna Aitpaeva \\ Astrakhan State University \\ Faculty of Agrobusiness, Technology \\ and Veterinary Medicine \\ Astrakhan, Russia \\ arman.bisaliev2012@yandex.ru
}

\begin{abstract}
None of the existing methods of determining food security of a region takes into account the congruence of food chemical structure with enzyme systems of the human organism. At the same time, providing the Russians with high-quality food is one of the main conditions for overcoming the depopulation at the federal and regional levels. The article dwells on criteria of assessing food security of a region that were formulated on the basis of an innovative approach of stereochemical congruence stating that a basic diet of the population of a certain area must consist of high-quality foodstuff made of local or locally adopted plant varieties and animal breeds, the chemical structure of which is congruent to the fullest extent with enzyme systems of the human organism. The methods of determining the level of food security of a region were tested on the example of the Astrakhan and Volgograd regions.
\end{abstract}

Keywords: food security, food quality, rules of chemical congruence

\section{INTRODUCTION}

For the first time the issue of food security was addressed by T. Malthus as early as in 1798. In his "Essay on the Principle of Population", he wrote that the laws of nature inevitably lead to the fact "that the power of population is indefinitely greater than the power in the earth to produce subsistence for man. Population, when unchecked, increases in a geometrical ratio. Subsistence increases only in an arithmetical ratio" [1].

On the contrary, K. Marx [2] was an active opponent of the Malthusianism. He believed that every production method had its own law of population. In his opinion, the capitalist society is characterized by relative overload (unemployment) that deprives a part of the population of subsistence.

T. Malthus's ideas gained renewed momentum in the mid20th century resulting in Neo-Malthusianism; it proclaimed impossibility of provision of growing global population with necessary foodstuff.

For the first time a concept of world food security was proposed by the FAO in 1973. According to the Concept, the world food security is understood as maintaining stability at foodstuff markets and availability of basic foodstuff in all countries. Addressing the food security problem implies application of both economic and uneconomic methods including administrative ones.

According to V.N. Ovchinnikov and N.P. Ketova [3], the food security strategy has the following structure:

- drawing up a description of external and internal threats to food security, of production output and total food consumption, their comparison with scientifically-proven standards;

- determining criteria and parameters of economic performance that meet the food security requirements and ensure proper food supply for the population of all the regions of the country;

- mechanism of ensuring food availability for all the population categories with regard to protection of its interests and income level on the basis of legal, economic and administrative measures taken by the government. 
I.I. Ilyinov notes [4] that external threats to food security include:

- unfavorable changes in the world food markets;

- changes in exchange rates;

- deterioration of imported food quality;

- use of food as a lever of foreign policy pressure on importing countries.

The most significant internal threats to food security are:

- reduction of national production output, foodstuff range pruning;

- limitation of food physical availability;

- worsening production potential of the agricultural sector;

- deterioration of national foodstuff quality;

- unstable food supply in certain areas.

V.N. Papelo, A.N. Radchikov and P.V. Skurikhin [5] describe food security as an ability of the government to guarantee satisfaction of the country population's needs in food at the level of its normal human life.

Under the modern conditions, the Russians' nutrition is still low on beef, milk and greengrocery of home production. Over the years of reforms, Russia lost its food security on high-value products of animal origin. Sanctions imposed by Western Europe and USA in the last few years revealed numerous problems in the Russian agriculture. The Russian government's understanding of the food security problem triggered development of the national agricultural sector.

At present, it is necessary to set the right priorities on the regional level. The main agri-food task of every region is to ensure meeting the food security standards to provide for people living in this territory. At the same time, a lot of Russian regions made an emphasis on growing most profitable croppers: sunflower, vegetables and potatoes, rather than meeting the standards of food self-sufficiency and providing for optimal development of crop and animal breeding when the transition to market relations took place. Widespread monoculture farming without considering scientifically based crop rotation in time and space led to a significant decrease in economic soil fertility. I. G. Ushachev, Academician of RAS, speaking at the third all-Russian congress of economistsagriculturists, mentioned that $98 \%$ of Russian croplands have negative mould balance. Much land is abandoned, overgrown with low forest cover, it undergoes irreversible processes of degradation. The loss of main resource of agricultural industry - earth - can result in catastrophic consequences [6]. In this context, transition to eco-economic principles of husbandry entailing efficient use of all resources utilized in agricultural industry is becoming urgent.

The level of food industry development in the region is largely dependent on the availability of cropland, hay meadows and pastures, soil type, economic fertility, effective heat sun (higher than 10C), and amount of precipitation. At present, the role of abiotic factors is decisive and difficult to regulate. Hence, it is essential to take them into account when location of agricultural production is defined. Every region should assess the edaphoclimatic and economic potential of its territories and set out the agri-food priorities compliant with the indicators providing for food self-sufficiency in terms of basic types of food.

One of the most common regularities determining the process of food assimilation on all stages of evolutionary development from a microbial cell to a human-being is the rule of stereochemical congruence of food chemical structures to organism's enzyme systems. It is important to emphasize that according to the rule of stereochemical congruence the diet of Russian population, including population of a definite region, should mainly consist of high quality domestically and regionally produced foodstuff.

Unfortunately, the methods to identify the level of food security, accounting for food quality indicators, have not yet been developed. The majority of methods assess only quantitative indicators of food security, leaving out the requirement of congruence of food chemical structure to human organism's enzyme systems. This context makes it topical to develop methodological fundamentals of assessing the level of regional food security, taking into account food quality. This research will permit to reveal main directions of solving food problem on the regional and federal level.

\section{MATERIALS AND Methods (MODEL)}

Methodological basis of the research is comprised by fundamentals of general economics, agricultural theory and agricultural sector economics. Our research employs the following the following methodological principles:

1. The principle of system analysis, setting forward the idea that food security in a state is the main competitive advantage of food sector.

2. The principle of complex analysis. Food security as a competitive advantage of food sector improves demographic processes and increases healthy and active life expectancy of population of the region.

3. The principle of the structural and functional approach to the analysis of the regional food sector efficiency. Food sector includes dairy and meat subsector, fruit and vegetable sector etc. Economic efficiency of operation on the regional level is to be analyzed and assessed from the point of view of aims and objectives of the research.

Methods of factor and level-sensitive analysis and synthesis, method of mathematical modeling in economics, structural-functional and classifying methods as well as system approach, methodological approach, including multidimensional metrics applied to assessing the efficiency of the regional food sector, were among the methods and approaches proposed and used to solve the problems formulated within the framework of the research. 


\section{RESULTS AND DISCUSSION}

At present, one of the most significant characteristics of Russian food sector is the asymmetrical agricultural development on the regional level. Sustainable development of regional food sector is based on optimal correspondence of resources available for production to natural conditions. Some subjects of the Russian Federation, for example the Volgograd region, have hit lower threshold of food security for many kinds of food. Others, like the Astrakhan region, cater to the needs of their own population, providing vegetables and potatoes, while they depend on import supplies for meat, milk, vegetable oil, fruit and some other kinds of food. Meanwhile, the Astrakhan region is a unique region characterized by favorable soil and climate conditions for growing not only vegetables, gourds and potatoes, but also fruit cultures, rice, as well as for breeding of dairy and beef cattle, sheep and goats, horses and camels.

However, today's regional meat production deficit is equal to $44 \%$, milk deficit - $56 \%$, fruit and berries deficit $86 \%$, grain $-73 \%$ (Table 1). The existing disproportions in the development of regional food sector when the lack of fodder and animal products is overlapped by surplus production of vegetables, gourds and potatoes inflicts significant damage on food security of the Astrakhan region and its population.

At present the region produces $50 \%$ less fodder than required by optimal livestock. The fodder cost accounts for $50 \%$ (or more) of total cost of animal products.

The actual number of livestock in the Astrakhan region exponentially differs from optimal value. Thus, it is 1.7 times smaller than optimal number of cattle, for instance, it is 117 times smaller than optimal number of swine and 2.1 times smaller than optimal number of poultry. On the contrary, the number of horses and that of goats and sheep is 3 and 1.6 times higher than necessary correspondingly [7]. Slow development rates of dairy and beef cattle breeding prevent the Astrakhan region from reaching the required indicators of food security concerning milk, beef; they need to be thoroughly analyzed and efficient management measures are to be taken to stabilize the situation.

The Volgograd Region bordering on the Astrakhan region achieved great progress in developing of agricultural sector and ensuring food security for people. The reason for this is that there are large areas of chernozem soil in the Volgograd region and the total amount of districts is 3 times more than in the Astrakhan region (33 and 11 respectively). However, the Volgograd region also faces problems of livestock underproduction. This is mostly due to the fact that collective and state farms were ruined and the shift from Simmental to black-and-white and Holstein-Friesian cattle.

Beginning from the late 1970s, the agricultural sector of the Volgograd region has totally obtained animal needs of people in biologically adequate and eco-genetically safe food.

The build-up rates of agricultural goods fluctuated in the region for the period of 1916-2016. That was due to edaphoclimatic, political and socioeconomic factors. The agro-industry was developed in the Volgograd region before 1975.
The build-up rates of agricultural goods fluctuated in the region for the period of 1916-2016. That was due to edaphoclimatic, political and socioeconomic factors. The agro-industry was developed in the Volgograd region before 1975.

The development of animal breeding was realized mainly in collective and state farms during the latter half of the $20^{\text {th }}$ century. Actions to minimize animal breeding were taken during that period, especially between the latter half of $1950 \mathrm{~s}$ and the first half of 1960s, though the development of animal breeding in public farms was not totally banned. There were various livestock systems, constantly improving, in collective and state farms in different zones of the region in the latter half of the $20^{\text {th }}$ century.

Meat production rates per capita were the lowest in the region in 1940 and 1950. Production of meat in carcass weight was much higher in the following years than in 1940 and 1950 and it surpassed the rational standard by $10 \%$ in 1975 . Production of milk per capita reached the rational standard in 1965 and surpassed it by $2 \%$ in 1970 . Milk production level dropped in the following years because of a severe drought in 1972 and a dry year in 1975. Milk production level began dropping and flunked to $95 \%$ of the rational standard by 1975 . Gross meat production level trended upwards from the mid 1970s and before 1990 in the Volgograd region.

Numerous dairy unit, highly mechanized dairy farm and fattening farm projects were constructed in the Volgograd region in the 1970s. Under that circumstances and where there was adequate feeding, Simmental cows ranked below blackand-white cattle in yield of milk per lactation and machine milking fitness. Beginning from 1978, the shift to breeding mainly black-and-white cattle in the dairy breeding of the region began. The increasing forage production and production of different and mainly high-quality fodder over a largely expanding area of irrigated land significantly improved the forage production potential, providing the level increase and animal feeding adequacy by $30 \%$ and more per a livestock unit. That encouraged many doubters to change their mind about chronic weakness of food resources for animal breeding in the region and, beginning from 1986, the mass holsteinisation of Simmental cattle started. In the meantime, experience of some farms (experimental production farm "Kamyshinskoe", state farm "Bezymyanskiy" and others) showed that the crossbreed of Holstein and Simmental cattle, especially, was second to Simmentals in realization of genetic productivity potential, disease resistance, production quality and its eco-genetic safety.

The proportion of high-quality beef in total volume of meet produced in the region was $44 \%$, proportion of pork $37 \%$, mutton $-4 \%$, fowl $-14 \%$.

Scientifically baseless shift from Simmental cattle to black-and-white, Holstein cattle and its high-blooded crossbreed, under the fodder production breakdown, was a significant reason of reduction of cattle stock, overall production of high-quality and eco-genetically secure milk and beef in the Volgograd region. That is why refinement of genetic pool of cattle and increase of its population are the major conditions to stabilize and increase the overall 
production level of high-quality and eco-genetically safe milk and beef along the area of rural villages, municipal entities and in the region in general.

Mass import of animal products led the majority of domestic farms that raise cattle to unprofitability. At the same time, imported milk and meat do not often meet the requirements of the State Standard concerning quality and safety. In the present context natives of Volgograd are not provided with high-quality and eco-genetically safe meat and dairy products at the rate of a preferable consumption standard that was set up by the State Agency for Nutrition Research Institute of the Russian Academy of Medical Sciences.

Authors of the article offer a method to define the level of region's food security. The essence of this method is in evaluation based on calculating of the index to show region's basic food self-sufficiency. That ratio is a correlation of an actual overall production of a selected food product and a necessary production level taking into consideration its chemical structure. Formulae to estimate the ratio to show food self-sufficiency are common and may be found in a large range of methods. But adjustment of the self-sufficiency ratios depending on the production quality is not shown in any of the methods. The adjustment of self-sufficiency ratios, considering qualitative characteristics of the food products produced, is a crucial part of the method to estimate region's food security in the current context. The reason for this is that there are many products on the regional market that do not meet the requirements of current standards and that are high in concentrates, stabilizers and other carcinogens that adversely affect population's health.

After the self-efficiency ratio for food in the region would be defined and adjusted it would be necessary to define the public consumption standard for domestic food which chemical structure would correspond to the enzyme system of human beings and bring along increased expectation of a healthy life for people in different Russian regions.

Determining the income of the population and, on this basis, the economic food accessibility is a necessary component of the method for assessing the level of food security in the region. There are two types of famine in the regions of Russia today. The first type of famine is typical for the majority of the population when the daily diet is deficient in the main types of nutrients. A small part of Russians (about $10 \%$ ) have incomes allowing them to buy expensive food products from the category of delicacies. At the same time, they experience hidden forms of famine as their daily diet is not balanced with basic nutrients because of poor food quality and does not belong to healthy food products.

At the final stage, the method for determining the level of food security in the region provides its integral assessment based on the following four key indicators: (1) self-sufficiency ratio depending on the food quality; (2) local food products consumption ratio mostly corresponding the enzyme body systems of the region's population, (3) economic and (4) physical food accessibility. To conduct an integrated assessment of the region's food security system, we suggest using the following system of indicators that form an integral assessment of the region's food security:

$$
\mathrm{I}_{\mathrm{RFSS}}=\mathrm{K}_{\mathrm{FSSR}}+\mathrm{K}_{\mathrm{LFC}}+\mathrm{E}_{\mathrm{A}}+\mathrm{F}_{\mathrm{A}}
$$

where $\mathrm{I}_{\mathrm{RFSS}}$ is an integral assessment of the region's food security system; $K_{\mathrm{FSSR}}$ is a food self-sufficiency ratio that takes into account food quality; $\mathrm{K}_{\mathrm{LFC}}$ is a share of food received from plants and animals of intra-regional selection in total volume of consumption; $\mathrm{E}_{\mathrm{A}}$ is an economic food accessibility; $\mathrm{F}_{\mathrm{A}}$ is a physical food accessibility for the absolute majority of the population of the region. The following scale is proposed for an integrated assessment of the region's food security system: 100 points stand for the optimal level of regional food security, 90-99 points - the level is high; $80-89$ points - the level is above the average; $70-79$ points stand for the average level; 60-69 points show that the level is below the average; 40-59 points - low level and 0-39 points - an unsatisfactory level of food security.

When carrying out an integrated assessment of the region's food security system, it is planned to calculate the most significant indicators for each of the 10 main types of food. Then it is presupposed to sum over all positions and determine the final score [8]. Each of the four indicators is maximally estimated at 2.5 points. The summation four overall indicators can maximally give 10 points. The summation of final scores for each type of food can be maximally 100 points and mean $100 \%$ food self-sufficiency.

The calculations showed that the level of food security in the Astrakhan Region can be estimated at 52.91 points (low). This means that the regional agro-industrial complex does not meet the needs of the region's population in basic types of food. The highest points got fish (8), vegetables (7.9) and potatoes (7.65) out of a possible 10 points for each type of food (Table 2). The worst results belong to meat, milk, fruits and berries, as well as to sugar and vegetable oil which are insufficiently produced in the region.

The calculations showed that the level of food security in the Volgograd region can be estimated at 72.49 points (average). This means that the regional agro-industrial complex generally provides for the needs of the population in basic types of food with the exception of meat, milk and sugar. 10 points - bread and table egg, 9 points - fish, 8 points - fruits and berries and about 8 points - vegetable oil, vegetables and potatoes out of a possible 10 points (Table 3 ). The worst results belong to meat, milk which are insufficiently produced in the region, as well as to sugar which is not produced in the Volgograd region.

At the same time, to solve the food problem at the regional level, it is necessary to develop scientifically based regional policies and programs that reflect the real situation in agriculture and the ways to improve it effectively, genetically and eco-economically. The implementation of these measures will ensure food security and a balanced healthy eating when the diets of the regions' population will mostly include highquality local food products. 


\section{CONCLUSION}

The conducted research made it possible to make a comparative analysis and test the method of determining the level of food security in the region allowing to take into account the qualitative characteristics of food products produced and consumed by the region's population. The method approbation and calculation of the following key indicators: self-sufficiency ratio for basic types of food taking into account the qualitative characteristics, local food products consumption ratio that most closely corresponds to the enzyme systems of the region's population, the economic and physical accessibility of food allowed to assess and compare the level of food security in the Astrakhan and Volgograd regions. The food safety of the Astrakhan region is low and is estimated at 53 points, and the food security of the Volgograd region is average (72.5 points).

TABLE 1. Production of Main Types of Food in the Astrakhan region in 2016

\begin{tabular}{|l|l|l|l|}
\hline $\begin{array}{l}\text { Type of } \\
\text { food }\end{array}$ & $\begin{array}{l}\text { Rational } \\
\text { consumption rate, } \\
\text { kg/capita/year }\end{array}$ & $\begin{array}{l}\text { Volume of } \\
\text { production in } \\
2016, \mathrm{~kg} / \text { capita }\end{array}$ & $\begin{array}{l}\text { Deficit, production } \\
\text { surplus, \% }\end{array}$ \\
\hline Grain & 110 & 29.2 & -73 \\
\hline Egg & 291 & $\begin{array}{l}34.4 \text { million } \\
\text { pieces }\end{array}$ & 18 \\
\hline Meat & 75 & $\begin{array}{l}41.9 \text { in carcass } \\
\text { weight }\end{array}$ & -44 \\
\hline Milk & 390 & 173 & -56 \\
\hline Potato & 117 & 315.3 & in 2.7 times \\
\hline $\begin{array}{l}\text { Vegetables, } \\
\text { cucurbits } \\
\text { crop }\end{array}$ & 139 & 1148 & in 8.3 times \\
\hline Fruits & 71 & 10 & -86 \\
\hline
\end{tabular}

TABLE 2. Integrated Assessment of Food Security System in the Astrakhan region

\begin{tabular}{|l|l|l|l|l|l|}
\hline Type of food & $\mathrm{K}_{\mathrm{FSSR}}$ & $\mathrm{K}_{\mathrm{LFC}}$ & $\mathrm{E}_{\mathrm{A}}$ & $\mathrm{F}_{\mathrm{A}}$ & $\mathrm{I}_{\mathrm{RFSS}}$ \\
\hline Bread & 0.35 & 0.12 & 2.5 & 2.5 & 5.47 \\
\hline Meat & 0.96 & 0.6 & 1.2 & 1.2 & 3.96 \\
\hline Milk & 0.86 & 0.54 & 1.3 & 1.3 & 4 \\
\hline Egg & 2 & 0.38 & 1.7 & 1.7 & 5.78 \\
\hline Fish & 2 & 2 & 2 & 2 & 8 \\
\hline Vegetables & 2.5 & 0.4 & 2.5 & 2.5 & 7.9 \\
\hline Potato & 2.3 & 0.35 & 2.5 & 2.5 & 7.65 \\
\hline Fruits and berries & 0.38 & 0.17 & 1.5 & 1.5 & 3.55 \\
\hline Vegetable oil & - & - & 1.6 & 1.6 & 3.2 \\
\hline Sugar & - & - & 1.7 & 1.7 & 3.4 \\
\hline Total & & & & & 52.91 points \\
\hline
\end{tabular}

TABLE 3. Integrated Assessment of Food Security System in the Volgograd region

\begin{tabular}{|l|l|l|l|l|l|}
\hline Type of food & $\mathrm{K}_{\mathrm{FSSR}}$ & $\mathrm{K}_{\mathrm{LFC}}$ & $\mathrm{E}_{\mathrm{A}}$ & $\mathrm{F}_{\mathrm{A}}$ & $\mathrm{I}_{\mathrm{RFSS}}$ \\
\hline Bread & 2.5 & 2.5 & 2.5 & 2.5 & 10 \\
\hline Meat & 1.8 & 0.6 & 1.2 & 1.2 & 4.8 \\
\hline Milk & 1.3 & 0.54 & 1.3 & 1.3 & 4.44 \\
\hline Egg & 2.5 & 2.5 & 2.5 & 2.5 & 10 \\
\hline Fish & 2 & 2 & 2.5 & 2.5 & 9 \\
\hline Vegetables & 2.5 & 0.4 & 2.5 & 2.5 & 7.9 \\
\hline Potato & 2.5 & 0.35 & 2.5 & 2.5 & 7.85 \\
\hline Fruits and berries & 2.5 & 2.5 & 1.5 & 1.5 & 8 \\
\hline Vegetable oil & 2.5 & 1 & 2 & 2 & 7.5 \\
\hline Sugar & - & - & 2 & 2 & 4 \\
\hline Total & & & & & 72.49 points \\
\hline
\end{tabular}

The conducted research determines the perspective directions connected with the necessity of further study of the problem of increasing the level of food security in the regions, as well as efficiency and competitiveness of the regional food complex.

\section{References}

[1] T.Malthus, Essay on the Principle of Population. London: St. Paul's Church-Yard, 1798, $126 \mathrm{p}$.

[2] K. Marx, Capital. Criticism of political economy. Selected works in 9 volumes. M.: Publishing of political literature, 1987.

[3] V.N.Ovchinnikov, N.P.Ketova, A.A. Lysochenko, [Ecologization of agricultural nature management as the food security imperative]. Journal of Economic Regulation, 2014, vol. 5, no. 2, pp. 105-114. (In Russ.)

[4] I.Ilinov, Formation and development of the regional system of food security. dis. ... cand. econ. sciences, Volgograd, 2002, pp. 45-57.

[5] VN Papelo, AN Radchikov, PV Skurikhin, Food Security of Russia: Current State and Mechanisms of Self, Novosibirsk, 2000, pp. 56-60.

[6] I.G. Ushachev, A.F. Serkov, Sostojanie i problemy obespechenija prodovol'stvennoj bezopasnosti strany. [Jelektronnyj resurs] Materialy VNIJeSH, 2009, URL: http:// www.vniiesh.ru/publications/Stat/4949.html

[7] G.V. Timofeeva, A.A.Aitpaeva, [Techniques for assessing the level of the region's food security through qualitative characteristics of food products]. National Interests: Priorities and Security, 2017, vol. 13, iss. 10, pp. 1910-1926. (In Russ.)

[8] G.V. Timofeeva, R.I. Akmaeva, A.A.Aitpaeva, [Food safety of the territory: innovative measurement technologies]. Novosibirsk: Bulletin of NSUEU, 2017, no. 4. pp. 36-43. (In Russ.) 